\title{
Sudden cardiac arrest in children in the general practitioner's practice
} Nagłe zatrzymanie krążenia u dzieci w praktyce lekarza podstawowej opieki zdrowotnej

\author{
'Department of Public Health, Wroclaw Medical University, Wrockaw, Poland \\ ${ }^{2}$ Department of Emergency Medicine, College of Rehabilitation, Warsaw, Poland \\ ${ }^{3}$ Department and Clinic of Anaesthesiology and Intensive Therapy, Faculty of Medicine, Wroclaw Medical University, Wrockaw, Poland \\ Correspondence: Michał Czapla, Department of Public Health, Wroclaw Medical University, Bartla 5, 51-618Wrockaw, Poland, tel.: +48535 599535, e-mail: michal.czapla@umed.wroc.pl
}

\begin{abstract}
Sudden cardiac arrest in children is a very rare occurrence in the general practitioner's office. There is no doubt that prompt initiation of cardiopulmonary resuscitation and good quality of cardiopulmonary resuscitation provided by healthcare professionals are crucial for increasing the chance of survival. Consequently, it is vital for primary care physicians and other staff working in primary care to be able to recognise sudden cardiac arrest. The legal system in Poland neither imposes an obligation on physicians to take Basic Life Support (BLS) training, nor does it specify how often medical professionals should refresh their skills. Certificates confirming the completion of European Resuscitation Council (ERC) courses in BLS are valid for 3 years. After that time, the course must be repeated, which increases the frequency of staff training in this field. It is also important to note that guidelines for the management of sudden cardiac arrest are updated by the European Resuscitation Council every 5 years. In the event of loss of consciousness, and impairment or complete absence of breathing occurring in a patient in the general practitioner's office, cardiac arrest should be suspected, and cardiopulmonary resuscitation should be initiated as soon as possible. Checking for a pulse is not currently recommended, and should be avoided both by medically untrained and professionally qualified medical staff. Since palpation of a pulse is not reliable as a determinant of the need for cardiopulmonary resuscitation, the decision to initiate resuscitation should be made based on the patient's complete picture. The paper presents the methodology of administering cardiopulmonary resuscitation to children over 1 year of age, and illustrates it with suitable photographs.
\end{abstract}

Keywords: cardiopulmonary resuscitation, sudden cardiac arrest, child

Streszczenie Nagłe zatrzymanie krążenia u dzieci występuje niezwykle rzadko w praktyce lekarza podstawowej opieki zdrowotnej. Nie ulega wątpliwości, że zarówno szybkie rozpoczęcie resuscytacji krążeniowo-oddechowej, jak i jej jakość zwiększają szansę przeżycia. Dlatego bardzo ważne jest, aby lekarz i personel podstawowej opieki zdrowotnej potrafili rozpoznać ten stan. System prawny w Polsce ani nie narzuca lekarzowi obowiązku uczestnictwa w kursie Basic Life Support (BLS), ani nie określa, jak często powinien w nim uczestniczyć. Certyfikat ukończenia kursu BLS Europejskiej Rady Resuscytacji jest ważny przez 3 lata. Po tym czasie kurs należy powtórzyć, dzięki czemu zwiększa się częstotliwość szkolenia personelu w tym zakresie. Istotna jest także informacja, że wytyczne dotyczące postępowania w nagłym zatrzymaniu krążenia są aktualizowane przez Europejską Radę Resuscytacji co 5 lat. W przypadku gdy w gabinecie lekarskim u pacjenta występuje utrata przytomności, brak oddechu lub nieprawidłowy oddech, należy podejrzewać zatrzymanie krążenia i jak najszybciej podjąć resuscytację krążeniowo-oddechową. Badanie tętna podczas nagłego zatrzymania krążenia nie jest obecnie zalecanym działaniem zarówno dla osób niezwiązanych z medycyną, jak i dla związanych z nią na co dzień. Ponieważ jego badanie nie jest wiarygodne, decyzję o wdrożeniu podstawowych zabiegów resuscytacyjnych należy podjąć na podstawie pełnego obrazu chorego. W pracy przedstawiono metodologię prowadzenia czynności resuscytacyjnych u dzieci powyżej 1. roku życia, ilustrując ją stosownymi fotografiami.

Słowa kluczowe: resuscytacja krążeniowo-oddechowa, nagłe zatrzymanie krążenia, dziecko 


\section{INTRODUCTION}

S udden cardiac arrest (SCA) in the pre-hospital setting is not common in the paediatric population. The prevalence is estimated at 8-9.8 cases per 100,000 population $^{(1)}$. Unlike in the adult population, where the most common causes of SCA are of cardiovascular origin, in children cardiac arrest is usually a result of injuries and respiratory failure due to neurological disorders, infections or impaired airway patency. The most prevalent causes of SCA change with the age of the child. In infants, cardiac arrest in the pre-hospital setting is usually related to sudden infant death syndrome (SIDS) and respiratory failure, while in older children the main cause is injury. The proportion of injuries as the primary cause of SCA grows steadily: from a dozen or so percent in infants to $47.1 \%$ in adolescents. Other conditions that may lead to cardiac arrest include neurological disorders and infections. Infections can cause respiratory failure by compromising airway patency (as in acute epiglottitis) or disturbing gas exchange (pneumonia), while severe, rapidly progressing infections may lead to sepsis and septic shock ${ }^{(2-5)}$.

Specialists in paediatrics, family medicine and internal medicine working on a daily basis in outpatient clinics encounter patients with SCA less frequently than medical practitioners of the same specialties working in hospitals. Sudden cardiac arrest may not be very prevalent on the individual level, but it is fairly common overall. In Ireland, $36 \%$ of general practitioner's (GP) practices reported having at least one case of SCA during a period of 5 years $^{(6)}$. Early recognition of SCA and initiation of cardiopulmonary resuscitation (CPR) by witnesses of the event contributes to a significant extent to the return of spontaneous circula$\operatorname{tion}^{(7)}$. Prerequisites for the appropriate administration of CPR include a good level of knowledge and regular training in CPR techniques ${ }^{(8)}$.

Even though the CPR procedure seems familiar, many studies worldwide show that people in various professions have a poor level of CPR knowledge and skills. It is estimated that only $30 \%$ of people attempt to resuscitate victims of sudden cardiac arrest before the arrival of the emergency medical services, the main reason being the lack of knowledge of CPR. Retaining CPR skills without refresher training and regular practice is difficult. Consequently, participation in courses and constant updating of knowledge are essential, especially in view of the fact that CPR recommendations are revised every 5 years by international guideline-developing organisations including the European Resuscitation Council (ERC) ${ }^{(9-11)}$.

Primary care physician play a key role in the survival chain consisting of four links: early recognition and calling for help, early initiation of CPR, early defibrillation to restore the heart's normal rhythm, and post-resuscitation care.

The refreshment of knowledge and presentation of key steps to be taken in paediatric patients with SCA will con-
A step-by-step CPR guide based on the updated ERC guidelines is shown in the chart below.

\section{STEP-BY-STEP GUIDELINE FOR CARDIOPULMONARY RESUSCITATION IN CHILDREN (FROM THE AGE OF 1)}

1. After ensuring your own safety and that of the child, check the child's responsiveness. Gently stimulate the child and ask loudly, for example "open your eyes" or "are you all right?" (Fig. 1).

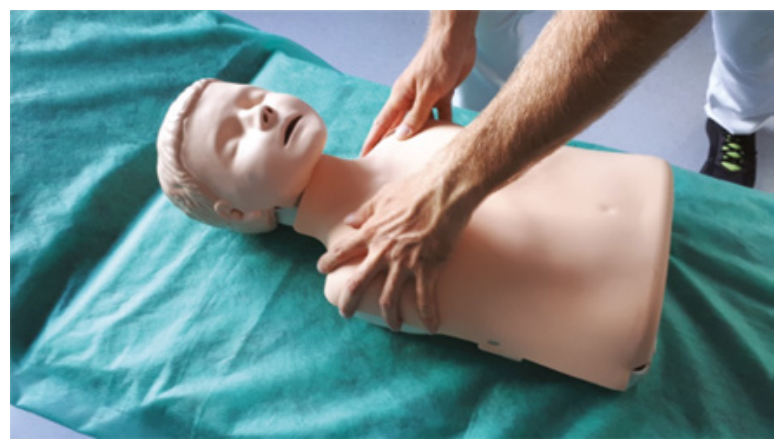

Fig. 1. Checking the child's responsiveness

2. If the child responds, for example by crying or moving, leave him/her in the position in which you find him/her (provided he/she is not in further danger), and call the emergency medical services. Reassess the child regularly until the arrival of paramedics.

3. If the child does not respond:

- Shout for help, especially if you are alone in the room. Call medical staff, ask a parent to go to another surgery and call a doctor or a nurse.

- Carefully place the child on his/her back on a hard couch or on the floor.

- Open the child's airway by tilting the head and lifting the chin (Fig. 2).

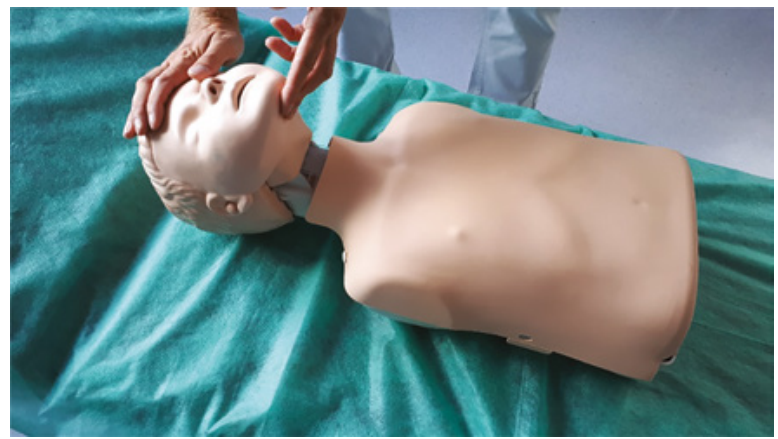

Fig. 2. Tilting the head and lifting the chin

4. Keeping the airway open, use your senses (i.e. look, listen and feel) to check for normal breathing. Put your face close to the child's face and for 10 seconds look for chest movements, listen for breath sounds, and feel for air movement on your cheek (Fig. 3). If you notice irregular, slow breaths, but there is no visible chest rise 
during inspiration (gasping), or if you have any doubt as to whether the child is breathing correctly, assume that the child's breathing is abnormal and proceed accordingly. Gasping may persist for up to several minutes after cardiac arrest ${ }^{(12)}$.

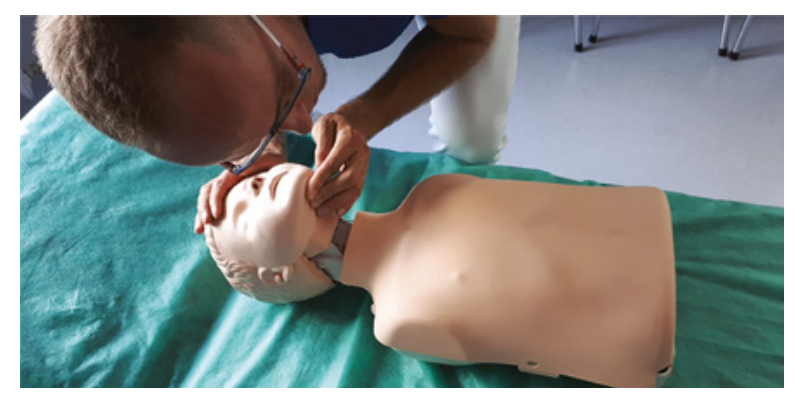

Fig. 3. Checking the child's breathing

5. If the child is unconscious but breathing normally, turn him/her on his/her side into the recovery position. In the case of spinal injury, leave the child in the position in which you find him/her.

6. If the child's breathing is not normal or absent:

- Check the airways for a foreign body. If there is an obvious airway obstruction, try to carefully remove it. Do not perform a blind finger sweep.

- Give 5 initial rescue breaths. Deliver effective breaths using mouth-to-mouth and a special mask (Fig. 4) or a bag valve mask (self-inflating bag) (Fig. 5).

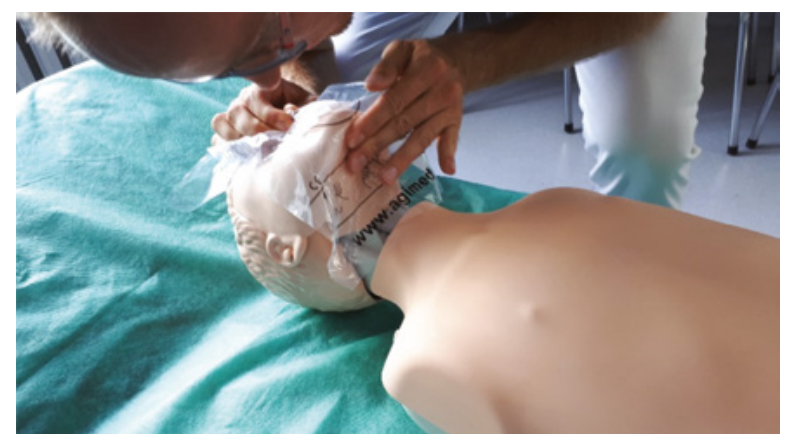

Fig. 4. Ventilation via face mask

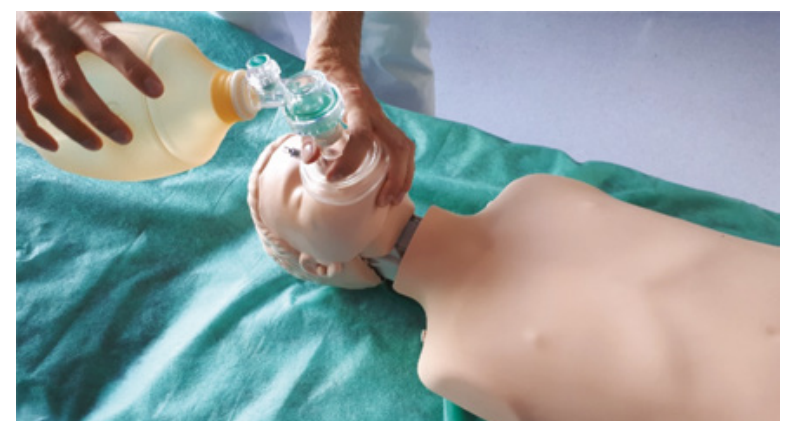

Fig. 5. Manual ventilation with a bag valve mask

- While performing CPR in children older than 1 year, check for airway obstruction before each breath (tilt the head and lift the chin). Pinch the soft part of the nose closed with the index finger and thumb of your hand on the child's forehead. Place your lips around the child's open mouth. Make sure that you have a good seal. Breathe slowly into the child's mouth for about 1 second to make the chest visibly rise. Repeat this sequence 5 times.

7. Assess the child's circulation. Take no more than 10 seconds to check for signs of circulation including any movement, coughing or normal breathing. You may check the pulse, but with limited training and experience this is not reliable, so proceed with CPR based on the patient's complete picture.

8. If you detect signs of circulation, continue rescue breathing, if necessary, until the child starts breathing effectively on his/her own. If the child breathes effectively on his/her own, turn him/her on the side into the recovery position and reassess regularly.

9. If you detect no signs of circulation:

Start chest compressions. Place the wrist of one hand on the child's sternum, one finger breadth above the xiphoid process. The fingers must be lifted to ensure that pressure is not applied over the child's ribs (Fig. 6). The compression must be sufficient to depress the sternum by at least one third of the anterior-posterior diameter of the chest or by $5 \mathrm{~cm}$. In larger children or for small rescuers, this can be achieved by using both hands, with the rescuer's fingers interlocked (Fig. 7).

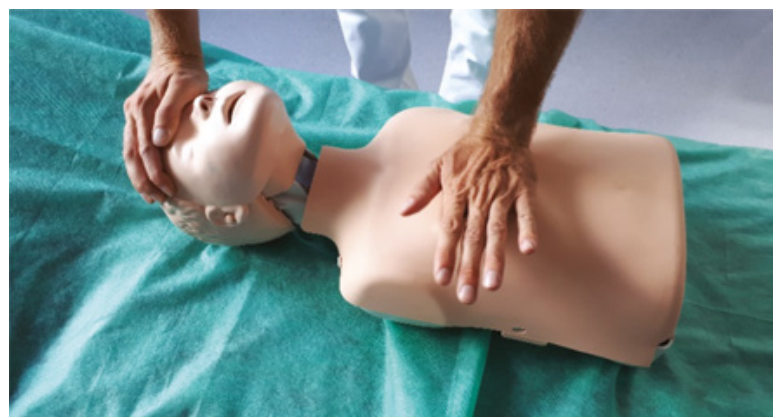

Fig. 6. One-hand chest compression technique

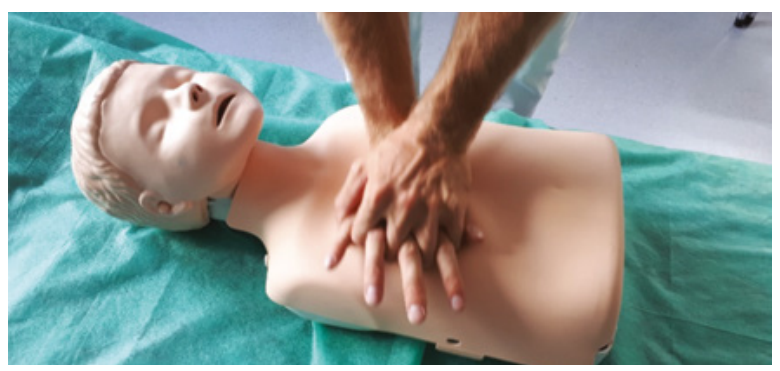

Fig. 7. Two-hand chest compression technique

10. Continue CPR until signs of circulation are restored or additional staff members arrive to help with CPR or take over the patient's management.

\section{CALLING FOR HELP}

If you are not alone, and you have someone to help in your surgery, immediately start $\mathrm{CPR}$, and send the other person 
to call an ambulance. However, you are alone (and shouting for help is ineffective), you should call the emergency medical services after 1 minute of CPR. If the child loses consciousness in front of the GP, and the physician suspects that the cause of SCA may be due to cardiovascular causes, the emergency telephone number should be called immediately, followed by the initiation of CPR. In such cases, it is highly likely that the child may need defibrillation. If the outpatient clinic has an automated external defibrillator (AED), it must be used immediately, following the applicable instructions.

In the management of paediatric patients in the GP's office, attention must be given to the fact that any disruption of the body's homeostasis may, after compensatory mechanisms are exhausted, rapidly lead to the systematic collapse of body systems, and ultimately result in cardiac arrest. Consequently, every child in a severe condition should be assessed with a focus on a quick evaluation of the body's vital systems, correct identification of physiological disorders that may lead to cardiopulmonary failure before it occurs, and immediate actions to guard against the aggravation of disorders.

When assessing the child's condition, the widely used ABCDE approach (Airway, Breathing, Circulation, Disability, Exposure/Examination) should be followed.

Respiratory assessment should include the frequency and depth of respiration, and the presence of respiratory effort or stridor. Chest auscultation should be aimed at detecting possible abnormal breath sounds such as crackles, wheezes or the absence of respiratory murmur. Pulse oximetry is very useful for quick and non-invasive measurement of the blood oxygenation level. It is also a good method of indirect assessment of distal circulatory compromise.

With respect to the cardiovascular system, the heart rate must be assessed first. Tachycardia is very common in children, and it represents the primary mechanism to increase cardiac output. In turn, bradycardia, on account of the specific physiological nature of children's cardiovascular system, indicates a dramatic depletion of the body's compensatory mechanisms, and heralds an impending cardiac arrest. Consequently, bradycardia in always a critical sign in a child, and requires fast and prompt action. Cardiovascular failure is also evidenced by disorders of peripheral perfusion, mainly extended refill time, low tension or non-palpable peripheral pulse, reduced arterial blood pressure or body temperature disorders. Circulatory failure, irrespective of its cause, leads to disturbed organ perfusion presenting as organ dysfunction: reduced diuresis in the kidneys or impaired consciousness indicating abnormal cerebral perfusion ${ }^{(12)}$.

\section{CONCLUSIONS}

Deterioration of the child's general condition and the collapse of mechanisms responsible for cardiorespiratory cardiac arrest. Therefore, attention should be focused on recognising severe general condition and taking prompt actions aimed at stabilising the child - and in the event of SCA initiating CPR immediately.

\section{Conflict of interest}

The authors do not report any financial or personal connections with other persons or organisations, which might negatively affect the contents of this publication and/or claim authorship rights to this publication.

\section{References}

1. Kämäräinen A: Out-of-hospital cardiac arrests in children. J Emerg Trauma Shock 2010; 3: 273-276.

2. Demaret P, Lebrun F, Devos P et al.: Pediatric pre-hospital emergencies in Belgium: a 2-year national descriptive study. Eur J Pediatr 2016; 175: 921-930.

3. Kuisma M, Suominen P, Korpela R: Paediatric out-of-hospital cardiac arrests - epidemiology and outcome. Resuscitation 1995; 30: $141-150$.

4. Houtekie L, Meert P, Thys F et al.: Prehospital paediatric emergencies in Belgium: an epidemiologic study. Eur J Emerg Med 2015; 22: 107-110.

5. Sulzgruber P, Poppe M, Lobmeyr E et al.: Advanced life support in pediatric out-of-hospital cardiac arrest - a two-year review and critical appraisal of quality of care and clinical outcome in a European metropolitan area. Resuscitation 2017; 114: e21-e22.

6. Colquhoun $\mathrm{M}$ : Resuscitation in general practice - time for action: editorial on: "The presence of resuscitation equipment and influencing factors at General Practitioners' offices in Denmark: a cross-sectional study" by Niegsch ML, Krarup NT, Clausen NE. Resuscitation 2014; 85: 5-6.

7. Kitamura T, Iwami T, Kawamura $\mathrm{T}$ et al.; implementation working group for All-Japan Utstein Registry of the Fire and Disaster Management Agency: Conventional and chest-compression-only cardiopulmonary resuscitation by bystanders for children who have out-of-hospital cardiac arrests: a prospective, nationwide, population-based cohort study. Lancet 2010; 375: 1347-1354.

8. Kim HM, Kang DY, Kim T et al.: Analysis of the awareness change of public CPR training in metropolitan Seoul from 2011 to 2015. J Coast Res 2017; Special Issue 79 - The $2^{\text {nd }}$ International Water Safety Symposium: 30-34.

9. Oermann $\mathrm{MH}$, Kardong-Edgren $\mathrm{SE}$, Odom-Maryon $\mathrm{T}$ et al.: Effects of practice on competency in single-rescuer cardiopulmonary resuscitation. Medsurg Nurs 2014; 23: 22-28.

10. Cierniak M, Bartczak M, Balcerzyk-Barzdo E et al.: The influence of the first aid training on the knowledge of middle school students. Polish Journal of Public Health 2012; 122: 176-180.

11. Wojczyk A: Stan wiedzy studentów pielęgniarstwa na temat resuscytacji krążeniowo-oddechowej. Higher School's Pulse 2015; 9 (2): 7-11.

12. Maconochie IK, Bingham R, Eich C et al.; Paediatric life support section Collaborators: European Resuscitation Council Guidelines for Resuscitation 2015: Section 6. Paediatric life support. Resuscitation 2015; 95: 223-248. 